\title{
Parenting Styles and Self-Help Skills of Kindergarten Learners
}

\author{
Pamela Joie T. Sobrebiga ${ }^{1}$ and Sharon Rose G. Medez ${ }^{2}$ \\ ${ }^{1}$ Nasanagan Elementary School, Negros Occidental, Philippines \\ ${ }^{2}$ University of Negros Occidental-Recoletos, Bacolod City, Philippines
}

\begin{tabular}{l} 
Article history \\
Submitted: 26 October 2020 \\
Revised: 10 November 2020 \\
Accepted: 12 November 2020 \\
\hline Keywords \\
Education \\
Early Childhood Education \\
Parenting Styles \\
Self-Help Skills \\
Descriptive-Correlational \\
Negros Occidental
\end{tabular}

Introduction. Parenting style has influenced children's development, particularly on behavior development and school readiness (Sanders \& Morawska, 2014). It is a strong predictor not only of the cognitive but also of the social-emotional developmental success in children. Quality care for children during the early years of development has been emphasized (Newman, 2017). To achieve developmental outcomes, children should develop independence by acquiring self-help skills or self-care skills, which enable them to look after themselves and socialize daily (Akhmetzyanova, 2014; Landry, 2014). Studies have associated parenting styles with the academic performance and social-emotional behavior of children (Seesurrun, 2015); however, the literature on parents' role, particularly on children's self-help skills, is very limited. Thus, this study assessed the dominant parenting styles of a district in Negros Occidental during the school year 2018-2019 and the learners' level of self-help skill. It determined the differences in the learners' self-help skills in terms of parents' sex, family monthly income, employment status, marital status, and the relationship between parenting styles and self-help skills.

Methods. This study used descriptive-comparative and correlational research design. The descriptive design was used to determine the parenting styles and the level of self- help skills of learners. Comparative analysis was employed in analyzing the data in terms of the identified variables. The correlational research design was applied to determine the relationship between parents' parenting styles and the self-help skills of kindergarten learners. A reliability tested and validated modified questionnaire based on Baumrind's Parenting Typology was administered to 251 parents selected through stratified random sampling. The instrument used to assess the learners' self-help skills was based on the Philippine Early Childhood Development (ECD) Checklist. Analysis of the parenting styles used frequency and percentage. In contrast, data analysis of the self-help skills of learners used mean and standard deviation. The comparative analysis used t-test, Analysis of Variance (ANOVA), and correlational analysis through Chi-square.

Results. The dominant parenting style employed by parents was authoritative, characterized by the balance between warm, supportive, encouraging approach but with firmness in enforcing rules (Kiadarbandsari, Madon, Hamsan, \& Nouri, 2016). They are assertive but not intrusive and restrictive (Kuppens \& Ceulemans, 2018). In terms of sex, both groups are dominantly authoritative and least neglectful, but more females than the males were authoritative. Regarding family monthly income, the majority were authoritative except the 6,000-10,000Php earners who were authoritarian by using absolute standards in shaping behavior (Kuppens \& Ceulemans, 2018). On marital status, the married, widowed, and guardians were authoritative. However, single parents were authoritarian, most likely because they reared their children alone. By employment status, those with sideline work and the casually employed were authoritative or authoritarian. Concerning the level of self-help skills, when the learners were taken as a whole and grouped according to parents' sex, monthly family income, and employment status, they had slightly advanced development. Notably, the learners raised by guardians had average development in all skills, indicating lower level of self-help skills than those with complete parents. Moreover, there was no significant difference in the learners' self-help skills regarding the parents' sex, monthly family income, and employment status. However, there was a significant difference in terms of marital status, particularly between the guardians and the single, married, and widowed parents. Finally, there was a significant relationship between parenting styles and self-help skills, suggesting the influence of the parents' authoritative style on developing the learners' self-help skills. 
Conclusion. Most respondents' authoritative parenting style guaranteed that kindergarten learners are brought up in a balanced environment. Parents exhibited an understanding of their roles in children's development. They set firm rules but also provide a warm, supportive, and encouraging environment. In accordance with Bronfenbrenner's Ecological Systems Theory and Self-Determination Theory, this study has concluded that a balanced environment could indeed enable young children to acquire the holistic development that can propel them to learn and acquire adaptive or self-help skills. Therefore, kindergarten learners' slightly advanced self-help skills can be attributed to their parents' encouragement and motivation.

Practical Value of the Paper. The study significantly contributes to the few existing literature on the relationship between parenting styles and the self-help skills of kindergarten learners. The findings served as the baseline in designing the output, Support Program for Kindergarten Parents, that may empower parents, who are the most critical stakeholders and partners, to collaborate with the district in terms of education.

\section{References}

Akhmetzyanova, A. I (2014). The development of self- care skills of children with severe mental retardation in the context of Lekoteka. World Applied Sciences Journal, 29 (6): 724-727, 2014. DOI: 10.5829/idosi. wasj.2014.29.06.13922

Kiadarbandsari, A., Madon, Z., Hamsan, H. H., \& Mehdinezhad Nouri, K. (2016). Role of Parenting Style and Parents' Education in Positive Youth Development of Adolescents. Pertanika Journal of Social Sciences \& Humanities, 24(4).

Kuppens, S \& Ceulemans, E (2018). Parenting styles: A closer look at a well-known concept. Journal of Child and Family Studies. Retrieved from https://doi.org/10.1007/s10826- 018-1242-x

Landry, S. H. (2008). The role of parents in early childhood learning. Encyclopedia on early childhood development, $1-6$.

Newman, M. (2017). The Relationship Between Parenting Style and Self-Regulation in Early Childhood.https://doi. org/10.33015/ dominican.edu/2017.HONORS.ST.19

Sanders, M. \& Morawska, A. L. I. N. A. (2007). Can Changing Parental Knowledge, Dysfunctional Expectations and Attributions, and Emotion Regulation Improve Outcomes for Children. Parent Ski.

Seesurrun, S. (2015). The development of a self-help skills education programme for a group of visually impaired children (Doctoral dissertation, University of South Africa).

\section{Correspondence:}

Pamela Joie T. Sobrebiga [pjoiesobrebiga@gmail.com]

https://orcid.org/0000-0003-2527-3446 